\title{
Próba uruchomienia studium generalnego dominikanów we Wrocławiu na początku XV wieku
}

\begin{abstract}
Zarys treści: Autor stara się wykazać, że w 1407 r. dominikanie we Wrocławiu podjęli próbę uruchomienia przy swoim konwencie studium generale. Miało zostać przeniesione z Krakowa, gdzie jego funkcjonowanie napotkało problemy kadrowe. Pomysł przeniesienia studium popierał zrazu prowincjał zakonu, a zwieńczeniem zabiegów miała być kapituła generalna we Wrocławiu. Wobec oporu braci z Krakowa plan nie został jednak zrealizowany.
\end{abstract}

Content outline: The author argues that in 1407 the Dominicans of Wrocław made an attempt at forming the studium generale in their monastery. It was to be moved from Cracow, where its functioning was endangered by lack of faculty members. The idea was initially supported by the provincial of the order and the decision was to be made at the meeting of the general chapter in Wrocław. However, as the brethren of Cracow opposed the project, the plan was not realised.

Słowa kluczowe: dominikanie, prowincja, konwent, szkolnictwo, studium, lektor, regens

Keywords: Dominicans, province, convent, schools, studium, lecturer, regens

W aktach kapituły generalnej Zakonu Kaznodziejów z 1405 r. zapisano, że kolejne takie zgromadzenie odbyć się winno za dwa lata we Wrocławiu ${ }^{1}$. W wyznaczonym terminie przedstawiciele wszystkich prowincji zakonu nie zjechali jednak na Śląsk. $\mathrm{Z}$ nie do końca jasnych powodów obrady kapituły zostały przeniesione do Bolonii. Domyślamy się, że we wrocławskim klasztorze św. Wojciecha decyzję o niedojściu kapituły do skutku przyjęto z pewnym rozczarowaniem. Podjęto już zapewne jakieś przygotowania. Przypuszczalnie liczono, że obrady tak wielkiego i ważnego gremium wzmocnią rangę konwentu wrocławskiego w życiu nie tylko polskiej prowincji, lecz także całego zakonu. Z owymi nadziejami mogła wiązać się sprawa utworzenia we wrocławskim konwencie prestiżowego studium generale. Na początku 1407 r., zaledwie kilka miesięcy przed wyznaczonym terminem kapituły, jeden z wrocławskich lektorów wystąpił na dokumencie wystawionym przez konwent z tytułem regensa ${ }^{2}$. Zgodnie z zakonną praktyką należał się on przełożonemu najważniejszej szkoły $\mathrm{w}$ prowincji.

${ }^{1}$ Acta capitulorum generalium Ordinis Praedicatorum, t. III, wyd. B. M. Reichert, w: Monumenta Ordinis Praedicatorum historica, t. VIII, Romae 1900 (dalej cyt.: ACGOP), s. 133.

${ }^{2}$ Wrocław, Archiwum Państwowe (dalej cyt.: APWr.), rep. 57, nr 56 (108). 
Przypuszczenie, że na przełomie XIV i XV w. śląscy dominikanie zamierzali uruchomić we Wrocławiu studium generale wysuwał już o. Paweł Kielar $\mathrm{OP}^{3}$. Swoje domysły oparł zaś na przekonaniu o przewadze śląskiej kontraty nad pozostałymi częściami prowincji pod względem liczby studiów partykularnych, poziomu wykształcenia poszczególnych braci i wpływu na politykę prowincjałów. Inni historycy podeszli jednak do tej propozycji sceptycznie. Krzysztof Kaczmarek wskazał przede wszystkim na brak źródeł potwierdzających taką hipotezę i brak ośrodka uniwersyteckiego we Wrocławiu ${ }^{4}$. Przynajmniej niektóre przesłanki wskazane przez P. Kielara OP należy wziąć jednak pod uwagę. Niedawno o. Tomasz Gałuszka OP, na podstawie nowo odnalezionych źródeł, wykazał, że kontrata śląska zdecydowanie przodowała w XIV w. pod względem posiadanych na swoim terenie studiów partykularnych ${ }^{5}$. Przynajmniej od połowy XIV w. to Ślązacy obsadzali przeważnie godność prowincjała (Jan z Brzegu, Piotr z Chomiąży, Piotr Wasserrabe). Znany jest także separatyzm śląskich dominikanów. Wyraźnie objawił się on właśnie na przełomie XIV i XV w., zaczynając od buntu prowincjała Piotra Wasserrabego przeciwko generałowi w latach 1392-13936 , a kończąc na podziale polskiej prowincji w latach 1415-1417, gdy śląscy dominikanie przyłączyli się do prowincji Dolnych Niemiec (Theutonia Inferior) ${ }^{7}$. Dwadzieścia kilka lat dzielących te dwa wydarzenia określanych jest w literaturze mianem okresu ,walk wewnętrznych i prób oderwania Śląska od prowincji” oraz wzrostu znaczenia klasztoru wrocławskiego i rywalizacji o pierwszeństwo w prowincji z Krakowem ${ }^{8}$.

Nie można zaprzeczyć ambicjom śląskich dominikanów, gdy idzie o troskę o poziom wykształcenia i wpływ na losy prowincji. Wrocławski klasztor był w średniowieczu jednym z najważniejszych ośrodków intelektualnych polskiej prowincji.

${ }^{3}$ P. K i e l a r, Studia nad kulturą szkolną i intelektualną dominikanów prowincji polskiej w średniowieczu, w: Studia nad historią dominikanów w Polsce 1222-1972, t. I, Warszawa 1975, s. 345.

${ }^{4}$ K. K a c z m a r e k, Głos w dyskusji nad powstaniem Studium Generalnego dominikanów w Krakowie, Nasza Przeszłość 91, 1999, s. 88 (ciekawe, że autor wskazuje na brak ośrodka akademickiego we Wrocławiu, ale nieco wcześniej twierdzi, że nie był on konieczny do uruchomienia dominikańskiego studium); t e n ż e, Konwent dominikanów wrocławskich w późnym średniowieczu, Wrocław 2008, s. 152.

5 T. G a ł u s z k a, Szkolnictwo konwentualne i partykularne w strukturach polskiej prowincji dominikanów XIV stulecia. Nowe ujęcie w świetle nowych źródeł, Roczniki Historyczne 78, 2012, s. 206-209.

${ }^{6}$ R.-J. L o e n e rtz, Une ancienne chronique des provinciaux dominicains de Pologne, Archivum Fratrum Praedicatorum 21, 1951, s. 35-36; J. Kł o c z o w s k i, Dominikanie polscy na Śląsku w XIII-XIV wieku, Lublin 1956, s. 193-198; P. K i e l a r, Studia nad kulturą, s. 360-363; A. Z a j c h o w s k a, Franciszek Oczko i początki reformy obserwanckiej w polskiej prowincji dominikanów, Średniowiecze Polskie i Powszechne 4 (8), 2012, s. 208-216.

7 J. F i j ałe k, Dwaj dominikanie krakowscy Jan Biskupiec i Jan Falkenberg. W pięćsetną rocznicę odwołania satyry antypolskiej Falkenberga w Rzymie w 1424 roku, w: Księga pamiątkowa ku czci Oswalda Balzera, t. I, Lwów 1925, s. 287-296; J. T u r e k, Podział polskiej prowincji dominikanów w czasach prowincjalatu Jana Biskupca w latach 1415-1417, Przegląd Historyczny 106,2015 , z. 2, s. 287-324.

8 J. Kłoc z ow ski, Dominikanie polscy, s. 191-202; P. Ki e la r, Studia nad kulturą, s. $460-464$. 
Zgodni co do tego są wszyscy badacze. Powołanie studium generale mieściłoby się w tych dążeniach. Mało prawdopodobne jednak, aby w tym samym czasie próbowano uruchomić podobne szkoły w aż dwóch konwentach prowincji, a właśnie najpóźniej na początku XV w., jak się obecnie przyjmuje, powstało takie studium w Krakowie. Wspomniany już P. Kielar OP postawił hipotezę, że rozpoczęło ono swoją działalność w 1394 r. ${ }^{9}$. Pogląd ten poddał krytyce K. Kaczmarek, który określił czas powstania krakowskiego studium na lata $1405-1410^{10}$. Maciej Zdanek uważał natomiast, że proces tworzenia uczelni przypadał na lata $1403-1405^{11}$. Z kolei T. Gałuszka OP wykazał niedawno w przekonujący sposób, że brak znanych obecnie wzmianek źródłowych, zwłaszcza w (rzadkich) zarządzeniach kapituł generalnych dotyczących nominacji dla wykładowców i asygnacji studentów, nie musi jeszcze świadczyć o tym, że studium zaczęło działać dopiero na początku XV w. ${ }^{12}$ Podsumowując tę dyskusję, możemy przyjąć, że krakowskie studium generale powstało gdzieś na przełomie XIV i XV w., a z całą pewnością funkcjonowało już na początku tego drugiego stulecia.

Kim zatem był ów wspomniany regens wrocławski i czy możliwe było powstanie studium generale we wrocławskim klasztorze św. Wojciecha? Poszukując odpowiedzi na te pytania, powinniśmy przede wszystkim zastanowić się, jakie były konieczne warunki do uruchomienia takiego studium i jakie ślady źródłowe winno ono pozostawić po sobie. Zacznijmy od ogólnej uwagi, że studium generale mogła powołać wyłącznie kapituła generalna. To samo zgromadzenie mogło także mianować kadrę wykładowców, którą stanowili: regens kierujący pracami studium, kursor objaśniający Sentencje Piotra Lombarda, lektor prowadzący wykłady z Biblii oraz mistrz studentów ${ }^{13}$. Wiadomo jednak, że odnalezienie tego typu informacji w zachowanych i wydanych zarządzeniach kapituł generalnych nie jest sprawą oczywistą ${ }^{14}$. Nie dysponujemy także aktami kapituł prowincjalnych z początku XV w., w któ-

${ }^{9}$ P. K i e 1 a r, Studia nad kulturą, s. 334-356.

${ }^{10}$ K. K a c z m a r e k, Głos w dyskusji, s. 77-100; t e n że, Szkoły i studia polskich dominikanów w okresie średniowiecza, Poznań 2005, s. 339-345.

${ }^{11}$ M. Z d a n e k, Szkoły i studia dominikanów krakowskich w średniowieczu, Kraków 2005, s. 107-111.

${ }^{12}$ T. G a ł u s z k a, Studium generalne dominikanów polskich w XIV wieku?, Folia Historica Cracoviensia 20, 2014, s. 35-63.

${ }_{13}$ M.M. M u l c h a h e y, „First the Bow is Bent in Study...”. Dominican Education before 1350, Toronto 1998, s. 379; K. K a c z m a re k, Szkoły, s. 315.

${ }^{14}$ Nie zachowała się żadna wzmianka na temat mianowania pierwszego znanego regensa krakowskiego, którym był Jan Falkenberg, zob. K. K a m c z a r e k, Szkoły, s. 480, nr 188; M. Z d a n e k, Regensi dominikańskiego studium generalnego w Krakowie do 1596, Przegląd Tomistyczny 16, 2010, s. 112-113. Wiadomości o pierwszej znanej nominacji dla wykładowców krakowskiego studium pochodzą z $1410 \mathrm{r}$. W aktach kapituły generalnej zapisano jednak jedynie, że Jan Biskupiec został mistrzem teologii (ACGOP III, s. 141). Wiadomość na temat nominacji dla regensa, lektora i mistrza studentów przekazał dopiero piszący w XVIII w. Wawrzyniec Teleżyński OP (Biblioteka Kórnicka PAN, rkps 93, De rebus Provinciae Poloniae S. Hyacinthi Ord. Praedicatorum, k. 243). Do biografii Mikołaja Lypoldi, który został wówczas lektorem Sentencji (K. K a c z m a r e k, Szkoły, s. 417, nr 59), należy dodać, że w 1408 r. był przeorem w Cieszynie (Regesty dokumentów przechowywanych na Górnym Śląsku, t. II, opr. A. Barciak, K. Müller, Opava-Opole-Katowice 2011, nr 70). 
rych można by znaleźć jakieś wzmianki na ten temat ${ }^{15}$. Informacji należy zatem poszukiwać gdzie indziej. Dobrym źródłem okazują się niewykorzystywane dotąd dokumenty wystawione przez konwent wrocławski, w których można odnaleźć imiona kilkunastu lektorów ${ }^{16}$. Konieczne będzie jednak zachowanie ostrożności, gdyż podobne tytuły mogli nosić zarówno wykładowcy studium generalnego, jak i niższych w hierarchii systemu szkolnego dominikanów studiów partykularnych. W pierwszej kolejności należy zatem zebrać informacje na temat wszystkich lektorów, a następnie ustalić, jakie szkoły działały na terenie klasztoru św. Wojciecha. Dopiero na tej podstawie będzie można odpowiedzieć na pytania o wspomnianego regensa i studium generale.

I.

Badacze dziejów wrocławskich dominikanów w średniowieczu nierzadko przywołują regest zaginionego dokumentu z 3 VI 1404 r., w którym wymienieni zostali trzej lektorzy i kursor ${ }^{17}$. Historycy zdają się przy tym sądzić, że była to jednostkowa sytuacja. Tymczasem już o. Gabriel M. Löhr OP sygnalizował na podstawie tego przekazu, że na początku XV stulecia we Wrocławiu stale przebywało kilku lektorów ${ }^{18}$. Taką opinię potwierdzają źródła. W 1404 r. spotykamy w istocie nie trzech, ale aż pięciu lektorów. We wspomnianym (zaginionym dzisiaj) dokumencie konwentu z 3 VI tego roku wymieniono ich trzech: Augustyna, Pawła Mundila i Jana z Chomiąży (a także kursora Macieja), natomiast w dokumencie z 4 XI tego roku (poważnie uszkodzonym) spotykamy lektorów Pawła Mundila i Piotra Gerstmana (i znowu kursora Macieja z Brześcia), a przypuszczalnie wymieniono tam jeszcze jedno imię ${ }^{19}$. Na tym nie koniec. Przy okazji zatwierdzenia na funkcji inkwizytora

15 Pierwsze pełne akta kapituły prowincjalnej pochodzą dopiero z 1429 r.: Acta capitulorum Provinciae Poloniae Ordinis Praedicatorum, t. I, wyd. R.F. Madura, Romae 1972, s. 20-23; wcześniejsze akta znane są ułamkowo: T. G a ł u s z k a, Fragment akt kapituły prowincjalnej dominikanów polskich z lat dziewięćdziesiątych XIV wieku. Studium historyczne i edycja tekstu, Roczniki Historyczne 79, 2013, s. 119-145.

${ }^{16}$ Większość informacji podanych poniżej pochodzi z dokumentów wystawionych przez konwent w latach 1390-1424 i przechowywanych obecnie w Archiwum Państwowym we Wrocławiu. Ich edycji wraz z komentarzem przygotowuję osobno (Nos fratres conventus sancti Adalberti. Dokumenty konwentu dominikanów wrocławskich z lat 1390-1424).

17 APWr., rep. 135, nr 100 (regest w repertorium archiwalnym, s. 529-530). Zob. J. Kło c z o w s k i, Dominikanie polscy, s. 196; K. K a c z m a r e k, Konwent, s. 22; A. Z a j c h o w s k a, Franciszek Oczko, s. 205.

18 G. M. L ö h r, Breslauer Dominikaner des 15. Jahrhunderts auf auswärtigen Hochschulen, Archivum Fratrum Praedicatorum 13, 1943, s. 169; podobnie K. K a c z m a r e k, Szkoły, s. 143. Natomiast P. K i e 1 a r, Studia, s. 465, pisał, że dla lat 1400-1433 na podstawie ,informacji ubocznych" (niestety nie podał, jakich) można wymienić 20 lektorów.

19 APWr, rep. 57, nr 52 (104a). Po imieniu Pawła Mundila następuje luka na ok. trzy wyrazy, co uniemożliwia jednoznaczne stwierdzenie, czy był wówczas lektorem, ale opierając się na analogii do dokumentu z 3 VI, i porównując z miejscem zajmowanym po mistrzu teologii a przed lektorem, moża stwierdzić, że pełnił on wówczas tę funkcję. Po domniemanym słowie lector, a przed kolejnym imieniem znajdowało się prawdopodobnie imię jeszcze jednego nauczyciela, Jana z Chomiąży lub Augustyna. Imię tego drugiego z tytułem lektora znalazło się $\mathrm{w}$ uszkodzonym dokumencie z ok. 1404 r., umieszczonym w oprawie kodeksu Biblioteki Uniwersytetu Wrocławskiego (dalej cyt.: BUWr.), rkps I F 653. 
w diecezji wrocławskiej 15 IX 1404 r. biskup tytułował Jana Gliwicza słowami lector ordinis fratrum Predicatorum in Wratislavia ${ }^{20}$.

Wzmianki źródłowe z 9 I i 28 III $1405 \mathrm{r}^{21}$ potwierdzają, że w klasztorze św. Wojciecha było przynajmniej trzech lektorów i kursor, co istotne - w tym samym składzie, co jesienią poprzedniego roku: Piotr Gerstman, Paweł Mundil, Augustyn i Maciej z Brześcia. Prawdopodobne jest więc, że w drugiej połowie 1404 r. miejsce Jana z Chomiąży zajął Piotr Gerstman. To ważna informacja, gdyż do zmian w gronie wykładowców mogło dojść na kapitule prowincjalnej, która u polskich dominikanów tradycyjnie odbywała się jesienią. Do kolejnych zmian doszło w następnych dwóch latach. W lutym $1407 \mathrm{r}^{22}$ Paweł Mundil został zastąpiony przez Wojciecha (Albertus). Nowym kursorem był wówczas Ambroży, który kontynuował potem karierę naukową. W $1410 \mathrm{r}$. był już lektorem, obok Gerstmana i Augustyna ${ }^{23}$. W tym czasie czwartym lektorem został Mikołaj Bravensberg (Braunsberg/Braniewo), a kursorem Michał Gilgenborg (Gilgenburg/Szczytno). Mamy zatem nadal do czynienia z pewnym bogactwem. Kadra nauczająca wciąż obejmowała trzech lub nawet czterech lektorów oraz kursora, a zapewne także mistrza studentów.

Dopiero w 1415 r. zastanawia skromniejsza liczba lektorów. W dokumencie konwentu z 5 I tego roku z tytułem tym został wymieniony tylko Jan Gliwicz ${ }^{24}$. Wspomina się tam także kursora Marcina Kolbila. Taka zmiana może mieć związek z epidemią, która przeszła przez Śląsk w 1413 r. (wówczas mógł umrzeć Bravensberg, na temat którego milczą późniejsze źródła) oraz genueńską kapitułą generalną, która lektora Ambrożego posłała do Padwy z wykładami pro forma et gradu magisterii ${ }^{25}$. Należy jednak zwrócić uwagę, że w dokumencie ze stycznia $1415 \mathrm{r}$. nie wymieniono $\mathrm{z}$ jakichś powodów dwóch innych lektorów, nadal obecnych we Wrocławiu. Augustyn występował bowiem z tym tytułem jeszcze w latach dwudziestych $^{26}$. Wrocławia nie opuszczał też raczej Piotr Gerstman, który niebawem został tam przeorem ${ }^{27}$. Mógł nawet łączyć funkcje lektora i przeora, tak jak robił to jego następca Piotr Schiltberg ${ }^{28}$.

Wyjaśnić należy jeszcze jedną sprawę. W literaturze przyjmuje się, że w latach 1408-1414 lektorem we Wrocławiu był Piotr Wichman. Jako pierwszy przypuszczenie

${ }^{20} \mathrm{~W}$. W a t t e $\mathrm{n}$ b a c h, Über das Handbuch eines Inquisitors in der Kirchenbibliothek St. Nicolai in Greifswald, Abhandlungen der Königl. Akademie der Wissenschaften zu Berlin 1888, IV, s. 6. Zob. P. Kra s, Dominican inquisitors in medieval Poland (14th -15 th c.), w: Praedicatores inquisitores, t. I: The Dominicans and the Mediaeval Inquisition, Roma 2004, s. 299, nr 13.

${ }^{21}$ APWr., rep. 58, nr 153 i 154

${ }^{22}$ APWr., rep. 57, nr 56 (108).

${ }^{23}$ APWr., rep. 58, nr 172.

${ }^{24}$ APWr., rep. 58, nr 193 (194).

${ }^{25}$ Acta capituli generalis celebrati Genuae anno 1413, wyd. S. L. Forte, Archivum Fratrum Praedicatorum 26, 1956, s. 303.

${ }^{26}$ APWr., rep. 57, nr 92 (143); BUWr., rkps IV Q 25, k. 5.

27 Nowożytny kronikarz klasztoru zapisał, że od 1416 do 1419 r. Gerstman był przeorem wrocławskim, a w okresie jego urzędowania zaczęto prowadzić regestry przeorskie (BUWr., rkps IV F 221a, s. 58). Zob. J. T u r e k, Podział, dodatek nr 2.

${ }^{28}$ BUWr., rkps IV Q 25, k. 4v, 8; P. K i e l a r, Szkoły, s. 398-402. 
takie wysunął P. Kielar OP na podstawie dwóch mów Piotra Grotkego z lat 1426 i 1427. Ponieważ pierwszą z nich Grotke wygłosił z okazji objęcia lektoratu artium we wrocławskim klasztorze i dziękował w niej Wichamanowi, qui me a iuventute litterarum sciencia et doctrina nutrivit, dominikański historyk przyjął, że Wichman nauczał we Wrocławiu długo wcześniej29. Lata graniczne oparł na przesłankach źródłowych: w 1407 Wichman zapisał się na Uniwersytet Krakowski ${ }^{30}$, w 1413 r. zaś kapituła generalna skierowała go do Kolonii z wykładami pro forma et gradu magisterii ${ }^{31}$. Mając lukę w źródłach pomiędzy rokiem 1407 a 1413, P. Kielar OP przypuszczał, że w tym właśnie czasie Wichman przebywał we Wrocławiu, co zaakceptowali późniejsi badacze ${ }^{32}$. Przytoczone informacje źródłowe nie potwierdzają jednak tej tezy. Skądinąd wiadomo zaś, że w 1408 r. Wichaman był przeorem w Toruniu ${ }^{33}$. Do Wrocławia przybył dopiero po uzyskaniu tytułu mistrza teologii ${ }^{34}$, a wyjechał z miasta pod koniec 1427 r., aby objąć funkcję regensa krakowskiego studium generale g. $^{35}$.

${ }^{29}$ BUWr., rkps IV Q 25, k. 5; P. K i e 1 a r, Studia, s. 376, 426-427.

${ }^{30}$ Metryka Uniwersytetu Krakowskiego z lat 1400-1508, wyd. A. Gąsiorowski, T. Jurek, I. Skierska, przy współpracy R. Grzesika, t. I, Kraków 2004, s. 64.

${ }^{31}$ Acta capituli 1413, s. 302.

32 W. B u c i c h o w s k i, Lista lektorów dominikańskich prowincji polskiej (od erygowania prowincji do roku 1525), Przegląd Tomistyczny 6-7, 1997, s. 192, nr 890; A. L a t k o w s k i, Magister Piotr Wichman OP, Przegląd Tomistyczny 2, 1986, s. 231; R. K u b i c k i, Środowisko dominikanów kontraty pruskiej od XIII do połowy XVI wieku, Gdańsk 2007, s. 185186, nr 579; K. K a c z m a r e k, Szkoły, s. 143, 544, nr 457; M. Z d a n e k, Szkoły, s. 170; P. Kr a s, Dominican inquisitors, s. 307, nr 32.

${ }^{33}$ R. K u b i c k i, Środowisko, s. 185, datował ten fakt na 1407, z kolei P. K i e l a r, Studia nad kulturą, s. 374, na 1404 r.; Ł. M y s z k a, Dominikanie w Toruniu od XVI do XIX wieku. Katolicki zakon w protestanckim mieście, Kraków 2015, s. 51, wyjaśnił, że chodzi o 1408 r.

${ }^{34}$ Dysponujemy relacją autorstwa Jana z Ząbkowic, w której opisał on przebieg studiów Wichmana w Kolonii, in studio Roniensi (nazwa zepsuta), w Bolonii i Paryżu (G. M. L ö h r, Die Dominikaner an der Leipziger Universität, Vechta 1934, s. 108-109; P. K i e l a r, Studia nad kulturą, s. 376-379).

${ }^{35}$ P. Ki e 1 a r, Studia, s. 380, 426-427, na podstawie drugiej mowy Piotra Grotkego (z końca października 1427 r.), uważał, że Wichman objął wówczas funkcję regensa. Za nim poszli inni historycy (zob. przyp. 32). Krytycznie odniósł się do tego twierdzenia M. Z d a n e k, Regensi, s. 90-91. Warto przytoczyć słowa Grotkego, w których dziękował Nicolao de Pnewy dignissimo priori provinciali istius alme provincie, qui me - - ad hunc gradum, videlictet magistri studentium, - - promovit, - - patribus diffinitoribus, - - Petro Schiltborg sacre theologie lectori nec non priori huius almi conventus, qui me - - acceptat, - - Petro Wychman sacre theologie professori nec non regenti studii huius alme congregacionis, qui me - - instruxit, - - Johanni Brasiatoris sacre theologie professori nec non - - Augustino sacre theologie lectori (BUWr., rkps IV Q 25, k. 4v-5). Jak widać, tym samym przymiotnikiem (alma, almus) Grotke określał prowincję i klasztor wrocławski, a więc nie jest jasne, co miał na myśli, mówiąc o congregacio. M. Zdanek jest pewien, że chodzi o Wrocław, ale sądzę, że w porównaniu z pierwszą mową zaszła jednak w wypadku Jana z Ząbkowic istotna zmiana $\mathrm{w}$ pierwszej był wymieniony przed Wichmanem z uwagą me in hunc gradum promovit, teraz zajął dalsze miejsce bez dodatkowych komentarzy. Natomiast ostatnie wzmianki dotyczące pobytu Wichmana we Wrocławiu i udziału w głośnej polemice z Mikołajem Turgaw pochodzą z września 1427 r., wyjazd do Krakowa i nominacja na regensa mogły nastąpić dopiero po jesiennej kapitule prowincjalnej. W tej sytuacji uważam, że rację miał P. Kielar. 
II.

Wiemy już, że na początku XV w. przebywało we wrocławskim klasztorze przynajmniej kilku wykładowców. Przyjrzyjmy się teraz ich obowiązkom. Ściśle wiąże się zaś z nimi zagadnienie tytułów, którymi się posługiwali. Zazwyczaj nazywani byli w źródłach po prostu lektorami, musieli mieć jednak różne kompetencje ${ }^{36}$. Zarządzenia kapituły prowincjalnej z 1378 r. informują bowiem, że we Wrocławiu funkcjonowały wszystkie trzy rodzaje studiów partykularnych: logiki (artium), filozofii (naturarum) i teologiii ${ }^{37}$. Pojawiające się w literaturze wątpliwości, czy każde działało w sposób nieprzerwany w kolejnych latach ${ }^{38}$, rozwiewają się w świetle omówionych wcześniej wzmianek źródłowych. Jeden ze wspomnianych lektorów musiał być zatem lektorem głównym (lector principalis), kierującym najwyżej stojącym w hierarchii partykularnym studium teologii (wykłady z Sentencji Piotra Lombarda mógł w nim prowadzić także lector sententiarum lub cursor, choć kursor mógł także prowadzić wykłady w studium Biblii); w pozostałych upatrywać należy lektora artium oraz lektora naturarum, czyli philosophiae (w studium filozofii pracował także mistrz studentów). W klasztorze z całą pewnością obecny był także konwentualny lektor teologii.

O objęciu kolejnego w hierarchii lektoratu decydowało zdobyte już wykształcenie i doświadczenie. Wiadomości poświadczające, że przynajmniej niektórzy ze znanych nam wykładowców wrocławskich spełniali te warunki, przynoszą zachowane do naszych czasów fragmenty akt kapituł prowincjalnych: kapituła z 1378 r. mianowała Andrzeja z Berlina lektorem Sentencji w studium teologii w Legnicy, a wspomnianego Augustyna - lektorem artium i mistrzem studentów w Krakowie ${ }^{39}$. W 1390 r. obydwaj byli już we Wrocławiu ${ }^{40}$. Pierwszy został odnotowany jako lesemeyster of dem thume, co bez wątpienia oznacza lektora katedralnego, a więc zajmującego lektorat teologii w szkole katedralnej ${ }^{41}$. Natomiast Augustyn był kursorem, to znaczy wykładowcą w studium teologicznym w klasztorze. Wydaje się, że na początku XV w. osiągnął kolejny szczebel kariery naukowej jako lektor główny lub konwentualny. Pod koniec życia nazywany był lektorem sacre theologie ${ }^{42}$. Z kolei

${ }^{36}$ K. K a c z m a r e k, Szkoły, s. 143, niesłusznie, moim zdaniem, uznał wszystkich znanych mu lektorów z tego okresu (wymienia Augustyna, Jana de Chomeza, Pawła Mundila, Ambrożego i Mikołaja Tilgenera) za lektorów konwentualnych.

${ }^{37}$ P. K i e la r, Organizacja, s. 316. Na temat organizacji dominikańskiego szkolnictwa zob. M. M. M u l c h a h e y, First the Bow, s. 219-278; K. K a c z m a r e k, Szkoły, s. 167-208; T. Gału s zk a, Szkolnictwo, s. 191-211.

${ }_{38}$ Zob. K. K a c z m a r e k, Konwent, s. 142-143, który uważa, że jednoczesne funkcjonowanie wszystkich rodzajów studiów poświadczają dopiero asygnacje kapituł prowincjalnych $\mathrm{z}$ lat $1447-1470$.

${ }^{39}$ P. K i e la r, Organizacja, s. 315, 317 (w źródle występuje Andrzej Bellin tożsamy z Andrzejem z Berlina).

${ }^{40}$ APWr., rep. 58, nr 103.

${ }^{41}$ Zgodnie z wolą fundatora, Apeczki z Ząbkowic, funkcję lektora katedralnego mógł pełnić zakonnik (K. D o la, Wrocławska kapituła katedralna w XV wieku. Ustrój - skład osobowy - działalność, Lublin 1983, s. 255; K. S t o p k a, Szkoły katedralne metropolii gnieźnieńskiej w średniowieczu. Studia nad kształceniem kleru polskiego w wiekach średnich, Kraków 1994, s. 117-118; K. K a c z m a r e k, Szkoły, s. 163-164).

${ }^{42}$ Zob. przyp. 35. 
Jan Gliwicz, mający od 1384 r. doświadczenie jako lektor Sentencji w Brzegu ${ }^{43}$, dwadzieścia lat później wykładał raczej nieregularnie, poświęcając się pracy inkwizytorskiej. W wypadku pozostałych lektorów sprawy nie są już tak jasne. Paweł Mundil i Jan z Chomiąży nosili tytuł lektora przynajmniej od 1395 r. ${ }^{44}$ Wydaje się, że dekadę później byli raczej lektorami konwentualnymi niż wykładowcami w studium teologii lub filozofii. Źródła z tego okresu wspominają wszak o mistrzu studentów prowadzącym zajęcia w studium filozofii i kursorze pracującym w studium teologii ${ }^{45}$.

W dokumentach powstałych w konwencie wrocławskim w dniach 4 XI 1404, 9 I i 28 III 1405 oraz 4 IV 1410 r. ${ }^{46}$ Piotr Gerstman określany był słowami lector domus lub lezemeyster des hauses. Taki sam tytuł spotykamy w polskiej prowincji bodaj tylko raz. Wśród świadków wcześniejszego o ponad sto lat dokumentu biskupa płockiego występował Jan lector domus eiusdem. Badacze przyjmują, że chodzi tu o lektora konwentualnego ${ }^{47}$. Tytuł lector domus dużo częściej występował natomiast w prowincji niemieckiej, gdzie oznaczał lektora głównego (lector principalis) ${ }^{48}$. Dodajmy, że takim samym terminem w dokumencie z 4 IV 1410, a także w 1411 r. ${ }^{49}$, określony został również Ambroży. Nie mógł on jednak równocześnie razem z Gerstmanem kierować studium partykularnym. Sprawa dodatkowo komplikuje się przy interpretacji dokumentu z początku 1407 r., w którym Gerstman został przedstawiony słowami lector regens.

Sformułowanie regens zazwyczaj odnoszone było do kierownika studium generale. Do ukształtowania tego zwyczaju doszło jednak dopiero w pierwszym dziesięcioleciu XV w. ${ }^{50}$ Znane są zarządzenia kapituł generalnych (tylko one miały do tego uprawnienia) z tego okresu, mianujące poszczególnych braci pro regente lub in regentem ${ }^{51}$. W źródłach $\mathrm{z}$ włoskiej prowincji św. Dominika spotykamy również sformułowanie lector seu regens pro studio generali ${ }^{52}$. Rzadko natomiast pojawia się wersja lector regens. Nie jest ona jednak całkowicie wyjątkowa. Tak określano przełożonych szkół generalnych w innych zakonach mendykanckich,

${ }^{43}$ T. G a ł u s z k a, Fragmenty czternastowiecznych akt kapituł prowincjalnych dominikanów polskich w zbiorach Bayerische Staatsbibliothek w Monachium. Kapituła prowincjalna w Opatowcu w 1384 r., Studia Źródłoznawcze 51, 2013, s. 121.

44 APWr, rep. 58, nr 119.

${ }^{45}$ Mistrz studentów występuje w dokumencie konwentu z 1405, a kursor w 1. 1404, 1405, 1407, 1410, 1415: APWr, rep. 57, nr 52 (104a), 56 (108); 58, nr 153, 154, 172, 193 (194).

${ }^{46}$ APWr, rep. 57, nr 52 (104a); rep 58, nr 153, 154, 172.

${ }^{47}$ Kodeks dyplomatyczny Księstwa Mazowieckiego, wyd. J. T. Lubomirski, Warszawa 1863, nr 38; zob. K. K a c z m a r e k, Szkoły, s. 137, 398 nr 9.

48 G. M. L ö hr, Die Kölner Dominikanerschule vom 14 bis zum 16 Jahrhundert. Mit einer Übersicht über die Gesamtenwicklung, Freiburg 1946, s. 34, 37; W. S e n n e r, Meister Eckhart's life, training, career, and trial, w: A Companion to Meister Eckhart, Leiden 2013, s. 39-40. We wspominanym już regeście dokumentu z czerwca 1404 r. zapisano też cursor domus, nie mam jednak pewności, czy sformułowanie to pochodzi ze źródła; wymieniony tam został także subprior domus.

49 BUWr, rkps IV F 57, karta ochronna.

${ }^{50}$ M. Z d a n e k, Regensi, s. 81-82.

51 ACGOP III, s. 76, 77, 97, 129, 146.

${ }^{52}$ L. Garga n, Lo studio teologico e la biblioteca dei domenicani a Padova nel tre e quattrocento, Padova 1971, s. 47. 
np. u franciszkanów ${ }^{53}$. Analogii nie musimy jednak poszukiwać poza Zakonem Kaznodziejów. Z pomocą idą nam źródła z prowincji niemieckiej i saskiej. Możemy tam odnaleźć - choć niezbyt często - słowa lector regens, używane w odniesieniu do dwóch różnych stanowisk. Bywał tak określany lektor główny, który legat et disputet w partykularnym studium teologii ${ }^{54}$, ale zdarzało się również, że nazywano tak przełożonego i głównego wykładowcę studium generale ${ }^{55}$. Tak bywało w Kolonii ${ }^{56}$, a więc studium, które cieszyło się wśród polskich braci ogromnym prestiżem i do którego nierzadko byli oni wysyłani ${ }^{57}$ - także ci związani z Wrocławiem, żeby wymienić chociażby znanego nam już Jana Gliwicza ${ }^{58}$. Przejęcie niemieckiej (kolońskiej) nomenklatury mogło nastąpić w sposób naturalny, przez przeniesienie na rodzimy grunt dobrze znanych wzorców. Że sprawa tytulatury w polskiej prowincji dopiero kształtowała się na przełomie XIV i XV w., wskazuje zaś przypadek mistrza Franciszka Oczki. Jak słusznie zwracali uwagę badacze, użyty w jego przypadku tytuł lector summus właściwie nie jest znany w szkolnictwie dominikańskim tych czasów. Według P. Kielara OP oznaczał regensa, zdaniem innych (i słusznie) - lektora konwentualnego ${ }^{59}$.

Tytuł lector regens mógł zatem oznaczać głównego lektora w studium teologii lub przełożonego studium generalnego ${ }^{60}$. W pierwszym wypadku musielibyśmy

${ }^{53}$ B. R o e s t, A History of Franciscan Education (c. 1201 - 1517), Leiden 2000, s. 123.

${ }^{54}$ Najlepiej jego rolę ukazują akty normatywne. W zarządzeniach kapituł prowincji niemieckiej i saskiej z przełomu XIV i XV w. dotyczących obsady studiów zwraca uwage formularz: In X. legat et disputet A., sententias B., magister studentium C. W aktach kapituły z początku XVI w. występują: lector regens, cursor, magister studencium (np. Akten der Provinzialkapitel der Dominikanerordensprovinz Teutonia aus den Jahren 1398, 1400, 1401, 1402, wyd. B. M. Reichert, Römische Quartalschrift für christliche Altertumskunde und für Kirchengeschichte 11, 1897, s. 296-299, 305-309, 315-318, 325-329; F. B ü n g e r, Ein Dominikaner Provinzialkapitel in Luckau (1400), Zeitschrift für Kirchengeschichte 34, 1913, s. 80-85; por. Die Kapitel der Provinz Saxonia im Zeitalter der Kirchenspaltung 1513-1540, wyd. G. M. Löhr, Leipzig 1930, s. 163, 205, 223).

$55 \mathrm{~W} 1483 \mathrm{r}$. w przełożony berlińskiego studium generalnego występował z tytułem lektora regensa (G. A. M e i j e r, Het Jakopijnenklooster te Groningen, Archief voor de geschiedenis van het Aartsbisdom Utrecht 32, 1907, s. 319, nr 5).

${ }^{56}$ G. M. L ö h r, Die Kölner Dominikanerschule, s. 40.

${ }^{57}$ Zob. Zbiór formuł zakonu dominikańskiego prowincji polskiej z lat 1338-1411, wyd. J. Woroniecki, J. Fijałek, Archiwum Komisji Historycznej, t. XII, Kraków 1919-1938 (dalej cyt.: Zf), nr 127; Registrum litterarum fr. Raymundi de Vineis Capuani magistri Ordinis 1380-1399, wyd. T. Kaepelli, w: Monumenta Ordinis Praedicatorum Historica, t. XIX, Romae 1937, s. 146. W Kolonii studiował także regens krakowski Jan Falkenberg (F. B ü n g e r, Ein Dominikaner, s. 83).

${ }^{58}$ W kodeksie BUWr., rkps I F 194, k. 80, zapisano: Explicit iste liber fratris Iohannis de Glywicz ordinis fratrum Predicatorum provincie Polonie conventus Wratislaviensis per eum scriptus in Colonia dicta Agrippina anno 1383.

${ }_{59} \mathrm{P}$. K i e 1 a r, Studia nad kulturą, s. 334-356, 366, upatrywał w tym tytule potwierdzenia sprawowania przez Oczkę funkcji regensa krakowskiego studium generalnego. Za nim poszli A. La tk ow ski, Magister Franciszek Oczko OP, Przegląd Tomistyczny 2, 1986, s. 227; W. B u c i c h o w s k i, Lista, s. 102, nr 206. Inaczej natomiast: K. K a c z m a r e k, Głos w dyskusji, s. 89-92; t e n ż e, Szkoły, s. 405-406, nr 11; M. Z d a n e k, Szkoły, s. 107; A. Z a j c h ow sk a, Franciszek Oczko, s. 205.

${ }^{60}$ Podobne używanie słowa regens zdarzało się również w polskiej prowincji. W aktach kapituły prowincjalnej z $1450 \mathrm{r}$. mowa jest o dwóch nominacjach in regente - tymi samymi 
uznać go za synonim nazwy lector domus. Przyjmując jednak, że nie został użyty przypadkowo i w ten sposób chciano wyróżnić przełożonego studium generalnego, stajemy przed zasadniczym problemem. Skądinąd nie wiemy bowiem nic na temat funkcjonowania takiej szkoły we wrocławskim klasztorze św. Wojciecha na przełomie XIV i XV stulecia. Pewne fakty z ok. 1407 r. wskazują na inny scenariusz wydarzeń.

III.

Faktem jest, że ok. 1405 r. w krakowskim klasztorze Trójcy Świętej działało już studium generale, a z tytułem regensa występował Jan Falkenberg ${ }^{61}$. Nie trwało to jednak długo. Ten wywodzący się z prowincji saskiej zakonnik rozpętał niebawem gwałtowną kampanię przeciwko biskupowi krakowskiemu Piotrowi Wyszowi i biskupowi wormackiemu Mateuszowi z Krakowa. W rezultacie tych wydarzeń już w połowie 1406 r. wyjechał ze stolicy Królestwa Polskiego ${ }^{62}$. Po krótkim pobycie w Rzymie nie wrócił jednak do Krakowa, ale zatrzymał się w Pradze, gdzie podjął obowiązki profesorskie na inkorporowanym do miejscowego uniwersytetu dominikańskim studium generale g3. $^{6}$.

Zdaje się, że władze polskiej prowincji początkowo nie wiedziały, jak zareagować na zachowanie Falkenberga. Jego nagły wyjazd nie był, jak sądzę, jednoznaczny z utratą godności regensa, ale zdecydowanie utrudniał dalsze funkcjonowanie studium. Jesienią 1406 r. pozostało bowiem w Krakowie zaledwie dwóch lektorów, przy czym jeden (Jan Biskupiec) był równocześnie przeorem, a drugi (Piotr) - inkwizytorem ${ }^{64}$. Braki kadrowe i przedłużająca się nieobecność regensa powinny wymusić jakieś kroki. Sprawa obsady krakowskiej uczelni musiała stanąć na zbliżającej się kapitule prowincjalnej ${ }^{65}$.

słowami opisano mianowanie regensa studium generalnego w Krakowie, jak i przełożonego studium teologii w Gdańsku (Acta capitulorum Provinciae Poloniae Ordinis Praedicatorum, t. I, s. 39, 40).

${ }^{61}$ W. S e ń k o, Trzy traktaty Jana Falkenberga na temat tyranobójstwa przedstawione na soborze w Konstancji w 1416 r., Przegląd Tomistyczny 10, 2004, s. 124. Zob. K. K a c z m a re k, Szkoły, s. 480, nr 188; M. Z d a n e k, Regensi, s. 112-113.

${ }^{62}$ Zob. H. B o o c k m a n n, Johannes Falkenberg, der deutsche Orden und die polnische Politik, Göttingen 1975, s. 135-154; K. O ż ó g, Kościół krakowski wobec wielkiej schizmy zachodniej i ruchu soborowego u schyłku XIV i w pierwszej połowie XV wieku, w: Kościół krakowski w życiu państwa i narodu polskiego, Kraków 2002, s. 33-36; Z. K a ł u ża, Chronologie des premieres discussions ecclesiologiques a Cracovie (1404-1407), Rivista di storia della filosofia 52, 1997, nr 1, s. 111-127.

${ }^{63}$ J. K a d l e c, ̌̌eholní generálni studia při Karlově universitě v době předhusitské, Acta Universitatis Carolinae, Historia Universitatis Carolinae Pragensis 7, 1966, fasc. 2, s. 76-77.

${ }^{64}$ Kraków, Archiwum Polskiej Prowincji Dominikanów, perg. 98; regest: Zbiór dokumentów katedry i diecezji krakowskiej, t. I, wyd. S. Kuraś, Lublin 1965, nr 175. Owego Piotra często utożsamia się z Wichmanem (zob. P. K i el a r, Studia nad kulturą, s. 374; K. K a c z m a r e k, Szkoły, s. 544, nr 457; M. Z d a n e k, Szkoły, s. 110, 166). Moim zdaniem był to jednak lektor i inkwizytor występujący w Krakowie w 1. 1403, 1408 i 1414 (P. K r a s, Dominican inquisitors, s. 307, nr 31; M. Z d a n e k, Inkwizytorzy dominikańscy w diecezji krakowskiej w średniowieczu, w: Inkwizycja papieska w Europie Środkowo-Wschodniej, Kraków 2010, s. 233).

${ }^{65}$ Kapituły prowincjalne regularnie zajmowały się obsadą szkół, także generalnych, o czym świadczą chociażby przywoływane już akty kapituł niemieckiej i saskiej, w których zapisywano 
Efektem tych rozmów było zaś zapisanie się na Uniwersytet Krakowski w 1407 r. dwóch przeorów - krakowskiego Jana Biskupca i toruńskiego Piotra Wichmana ${ }^{66}$. Aby któryś z nich mógł objąć wakujące w czasie absencji Falkenberga obowiązki regensa, musiał najpierw uzupełnić wykształcenie. A to wymagało czasu.

Tak dochodzimy do konwentu wrocławskiego i wspomnianego lektora regensa. Występuje on 3 II 1407 r., a więc już ponad pół roku po wyjeździe Falkenberga z Krakowa, ale zapewne jeszcze przed jego przybyciem do Pragi, z całą pewnością przed immatrykulacją Biskupca i Wichmana na Uniwersytet Krakowski, zarazem zaś na trzy miesiące przed wyznaczonym terminem kapituły generalnej, która miała tym razem zebrać się we Wrocławiu. Należy wykluczyć możliwość, że w klasztorze św. Wojciecha próbowano uruchomić drugie studium generalne. Stawiam więc hipotezę, że w obliczu wyjazdu, a nawet niesubordynacji Falkenberga i niedostatków wykwalifikowanej kadry nauczycielskiej w Krakowie zdecydowano się przenieść studium generale do Wrocławia. Zdaję sobie sprawę, że nie mogła to być łatwa do przeprowadzenia operacja. Wrocław znajdował się poza granicami Królestwa Polskiego i nie było tu żadnej wyższej uczelni. Klasztor św. Wojciecha był jednak integralną częścią polskiej prowincji i drugim co do znaczenia konwentem, a przeniesienie studium nie było rozwiązaniem bez precedensu. Frankfurcka kapituła generalna z 1397 r. przypieczętowała fakt przejęcia przez studium generale zakonu w Bolonii roli, którą wcześniej odgrywał Paryż ${ }^{67}$. Sto lat wcześniej, po podziale prowincji rzymskiej, zdecydowano o przeniesieniu jej studium z Neapolu do Florencji ${ }^{68}$. Natomiast w 1478 r. kapituła generalna zaakceptowała utworzenie studium prowincji saskiej w Berlinie, w miejsce wcześniejszego znajdującego się w Magdeburgu ${ }^{69}$. Istnieją przesłanki wskazujące, że podobne przedsięwzięcie miało szanse powodzenia również we Wrocławiu:

Przede wszystkim działały tu wszystkie rodzaje szkół partykularnych, w których pracowali odpowiednio wykształceni bracia ${ }^{70}$. W klasztorze czynnych było jednocześnie kilku lektorów. Mieli oni do swojej dyspozycji znakomicie wyposażony księgozbiór ${ }^{71}$. Czy Piotr Gerstman mógł być jednak właściwym kandydatem do objęcia funkcji regensa? Aby tak było, powinien mieć za sobą odpowiednie wykształcenie.

także informacje na temat regensów - np. Kapitelsakten der Dominikanerprovinz Teutonia (1349, 1407), wyd. T. Kaeppeli, Archivum Fratrum Predicatorum 22, 1952, s. 194.

${ }^{66}$ Metryka Uniwersytetu Krakowskiego, t. I, s. 64.

${ }^{67}$ ACGOP III, s. 94-95.

${ }^{68}$ M. M u l c h a h e y, First the Bow, s. 384-390. Co ważne, nauczanie w Neapolu zostało wznowione po kilku latach (ACGOP I, s. 325).

${ }^{69}$ ACGOP III, s. 349.

${ }^{70}$ Poza braćmi posługującymi się w źródłach tytułami lektorów obecni byli tam także inni wykształceni zakonnicy. Przykładowo w 1407 r. wymieniony został Jan Strelin, być może tożsamy z bratem, który miał studiować ok. 1387 r. w Pradze (BUWr., rkps I Q 53, karta ochronna: Iste liber pertinet ad dominum Johannem Strelin, qui intravit in ordinem Predicatorum in Wratislavia, a na k. 82: Expliciunt excerpta sentenciarum finita Prage anno Domini millesimo trecentesimo octogesimo septimo in die sancti Stanyslai martiris; zob. P. K i e l a r, Studia nad kulturą, s. 328).

71 Zob. A. Ś w i erk, Fragmenty piętnastowiecznego katalogu biblioteki wrocławskich dominikanów, Śląski Kwartalnik Historyczny Sobótka 21, 1966, s. 541-556; K. Z a w a d z k a, Biblioteka klasztoru dominikanów we Wrocławiu (1226-1810), w: Studia nad historią dominikanów w Polsce 1222-1972, t. II, Warszawa 1975, s. 297-327. 
Regensi mogli zazwyczaj pochwalić się długoletnimi studiami i nierzadko tytułami mistrzów teologii, choć nie było to regułą. Tymczasem niewiele wiemy o wykształceniu Gerstmana ponad to, że w 1378 r. kapituła prowincjalna skierowała go do partykularnej szkoły teologii w jego macierzystym klasztorze świdnickim ${ }^{72}$. Później musiał kontynuować studia w którymś ze studiów generalnych (może w Pradze? ${ }^{73}$ ), skoro już w 1404 r. był głównym lektorem (lector domus). Należy także dodać, że to właśnie on stał na czele konwentu w okresie rozłamu w łonie prowincji, stając się wtedy bliskim współpracownikiem prowincjała separatystycznej prowincji Dolnych Niemiec (Theutonia Inferior), jako wikariusz kontraty śląskiej ${ }^{74}$. Wracając jednak do interesującego nas tu okresu, czyli pierwszej dekady XV w., trzeba podkreślić, że wśród wrocławskich dominikanów znajdował się mistrz teologii, z którym można próbować wiązać plany uruchomienia studium generalnego, jak sugerował już P. Kielar $\mathrm{OP}^{75}$. Może z powodu obaw o zachowanie jedności prowincji i oporu części braci, pamiętających wszak niedawne wydarzenia z lat 1392-1393, które doprowadziły do polaryzacji wspólnoty, nie mógł objąć funkcji regensa i została ona powierzona młodszemu Gerstmanowi.

Ów magister to Piotr Wasserrabe. Jan Długosz twierdził, że był Niemcem z Chełmna ${ }^{76}$, prawdopodobnie pochodził jednak ze Śląska ${ }^{77}$. Przypuszczalnie był lektorem głównym we Wrocławiu ${ }^{78}$, a od ok. 1385 r. prowincjałem. Jego rządy musiały wzbudzać jakiś sprzeciw, skoro w 1392 r. generał postanowił usunąc go $\mathrm{z}$ urzędu ${ }^{79}$. Wasserrabe zdołał jednak utrzymać się przy władzy. Niebawem zaś jak się przypuszcza - odmówił udziału dominikanów w odnowieniu Uniwersytetu

${ }^{72}$ P. K i e l a r, Organizacja, s. 316.

${ }^{73} \mathrm{Na}$ Uniwersytecie Praskim studiowali przypuszczalni krewni Piotra - Mikołaj Gerstman, Szymon Gerstman i Łukasz Gerstman ze Świdnicy - Liber decanorum Facultatis Philosophicae Universitatis Pragensis ab anno Christi 1367 usque ad annum 1585, cz. 1, Pragae 1830 (Monumenta historica Universitatis Carolo-Fernandinae Pragensis, t. I), s. 280, 281, 305, 400.

${ }^{74}$ Zob. J. Tu re k, Podział polskiej prowincji, dodatek nr 2.

${ }^{75}$ P. K i e 1 a r, Studia nad kulturą, s. 345.

76 R.-J. L o e n e rt z, Une ancienne chronique, s. 35.

77 Przydomka Wasserrabe używali niektórzy przedstawiciele rodziny rycerskiej z Cierni (Zirlau, Tschirn): Piotr (Petsche) burgrabia Rychbachu (Dzierżoniowa) i jego synowie regularnie występowali w dokumentach dotyczących księstwa świdnickiego-jaworskiego (Regesten zur schlesischen Geschichte, Codex diplomaticus Silesiae, t. XXII, XXIX, XXX, Breslau 19031930, nr 5033, 5387, 6522, 6868; Regesty śląskie, red. W. Korta, t. I-V, Wrocław 1975-1992, tu t. I, nr 752, t. II, nr 438, t. V, nr 46; Die landständische Verfassung von Schweidnitz-Jauer, wyd. G. Croon, Codex diplomaticus Silesiae, t. XXVII, Breslau 1912, s. 177; Landbuch księstw świdnickiego i jaworskiego, t. I-III, wyd. T. Jurek, Poznań 2000-2007, według indeksów). W 1394 r. jego syn, Jan Wassirrabe, sprzedał czynsz dominikankom wrocławskim (APWr., rep. 57, nr 118). W 1345 r. Petzke Wasserrabe kupił łan ziemi od komtura tucholskiego, a jakiś Wassirrabe odnotowany jest w spisach mieszczan toruńskich (Preussisches Urkundenbuch, t. III, wyd. H. Koeppen, Marburg 1958, nr 752; K. C i e s i e ls k a, Wykazy mieszczan toruńskich zobowiązanych do udziału w wyprawach krzyżackich na Gotlandię w latach 1398-1408, Zapiski Historyczne 32, 1967, z. 4, s. 94).

${ }_{78}$ P. K i e l a r, Organizacja, s. 316.

79 Zf, nr 152, 153, 155; zob. J. F i j a łe k, Wstęp, tamże, s. 246-248; R.-J. L o e n e r t z, Une ancienne chronique, s. 35-36; J. Kł o c z o w s k i, Dominikanie polscy, s. 193-198; P. K i e 1 a r, Studia nad kulturą, s. 360-363; A. Z a j c h ow s k a, Franciszek Oczko, s. 208-209. 
w Krakowie ${ }^{80}$. Swoją kadencję zakończył w 1395 r. ${ }^{81}$ W kolejnych latach podjął studia, których owocem był tytuł mistrza teologii, nadany mu przez kapitułę w $1401 \mathrm{r}^{82}$ Wkrótce były prowincjał wrócił do Wrocławia, gdzie nadal cieszył się dużymi wpływami, skoro pomimo kontrowersyjnej przeszłości i zaawansowanego już wieku został ok. 1404 r. wikariuszem prowincjała dla kontraty śląskiej ${ }^{83}$. Owym prowincjałem, z którym relacje mogły okazać się bardzo istotne dla omawianych spraw, był Jan Arnsberg, były przeor toruński, który najpewniej jesienią 1402 r. stanął na czele prowincji ${ }^{84}$. Jego obecność we Wrocławiu poświadczona jest w dokumentach wystawianych przez braci od św. Wojciecha 9 I i 28 III 1405, 3 II 1407 oraz 4 IV 1410 r. ${ }^{85}$ Tak częste wzmianki mogą wskazywać na stałe rezydowanie w stolicy Śląska. W takim wypadku Arnsberg wróciłby zatem do zwyczaju swoich poprzedników, którzy od połowy XIV w. (z wyjątkiem Andrzeja Rusińca) wybierali Wrocław na swoją siedzibę. Po krótkiej przerwie klasztor św. Wojciecha znowu stałby się najważniejszym ośrodkiem prowincji. Istnieje jednak również inna możliwość. Regularne pobyty Arnsberga we Wrocławiu mogą świadczyć o potrzebie intensywnego zajmowania się sprawami konwentu przejawiającego tendencje separatystyczne. Zwróćmy jednak uwagę na fakt, że to sam Arnsberg mianował swoim wikariuszem Piotra Wasserrabego, świadomie czyniąc go bliskim współpracownikiem i doradcą. Potwierdzając oficjalnie jego wpływy we wszystkich śląskich konwentach, musiał albo popierać jego zamierzenia, albo licząc się z jego siłą i względami wśród śląskich braci, iść na swego rodzaju ustępstwa. Dodajmy, że zarówno prowincjał, jak i Wasserrabe byli obecni przy spisywaniu dokumentu, w którym Gerstman został nazwany lektorem regensem. Uważam, że to właśnie Wasserrabe stał za koncepcją przeniesienia studium generale.

Aby zrealizować plany przenosin, potrzebne było odpowiednie zaplecze, nie tylko intelektualne, ale także materialne. Wrocławski konwent należał do największych i najmajętniejszych w prowincji. Związany blisko z mieszczaństwem wrocławskim, obracał niemałymi sumami pieniędzy. Z początku XV w. pochodzi kilka istotnych zapisów testamentowych i informacji o znacznych dochodach pozyskiwanych przez konwent (m.in. czynsz z domu na placu św. Wojciecha, dochód z dziedziny przed Bramą Oławską, prawo do Domasławia) ${ }^{86}$. W 1405 r. mniszki z klasztoru św. Katarzyny

${ }^{80}$ Zob. P. K i e la r, Studia nad kulturą, s. 347; T. G ału s zk a, Szkolnictwo, s. 209. Jako prowincjał przynajmniej kilka razy wizytował Kraków i był wówczas obdarowywany przez władze miejskie (Najstarsze księgi i rachunki miasta Krakowa od r. 1300 do 1400, wyd. F. Piekosiński, J. Szujski, Kraków 1878, s. 231, 236, 247).

${ }^{81}$ APWr., rep. 58, nr 119.

${ }^{82}$ Odpowiednią zapiskę kapituły wydał $\mathrm{T}$. K a e p p e 1 i, La raccolta di discorsi e di atti scolastici di Simone da Cascina O. P. († ca. 1420), Archivum Fratrum Praedicatorum 12, 1942, s. 227.

${ }^{83}$ APWr., rep. 135 D, nr 100, s. 529-530.

${ }^{84}$ R.-J. L o e n e r t z, Une ancienne chronique, s. 38; R. K u b i c k i, Środowisko, s. 162, nr 149; te nże, Dominikanie w Nordenborku i Gierdawach w XV - początkach XVI w., Komunikaty Mazursko-Warmińskie 2012, nr 2 (276), s. 230, przyp. 16; T. G a ł u s z ka, Podział dominikańskich okręgów klasztornych na Kujawach w połowie XIV wieku. Studium dokumentu prowincjała Ludolfa z 1517 roku, Roczniki Historyczne 80, 2014, s. 118-119.

${ }^{85}$ APWr., rep. 58, nr 56 (108), 153, 154, 172.

${ }^{86}$ APWr., rep. 135d, nr 100, s. 529-530; rep. 57, nr 52 (104a), 54 (106), 57 (109), 58 (110). 
przekazały braciom w sumie 72 grzywny groszy czeskich ${ }^{87}$, a w 1408 r. rada miasta Wrocławia ofiarowała konwentowi 15 grzywien czynszu ${ }^{88}$. Majątkiem dysponowali także poszczególni bracia. Najwyraźniej widoczny w tej mierze jest znowu Piotr Wasserrabe. W 1404 r. otrzymał on od księżniczki opawskiej i raciborskiej Agnieszki owce z dworu w Baborowie i Bojanowicach ${ }^{89}$. Najpewniej niedługo później je sprzedał, bo cóż innego miał z nimi czynić uczony dominikanin? Trzy lata później, właśnie 3 II 1407 r., przekazał konwentowi 30 grzywien groszy czeskich, w zamian za co otrzymał 3 grzywny rocznego czynszu z domu na placu św. Wojciecha ${ }^{90}$. Transakcję tę poświadcza cytowany wyżej dokument, w którym Gerstman występuje jako lector regens. Zawarty w nim układ zatwierdził prowincjał Jan Arnsberg, a Wasserrabe działał tu ex speciali affectu, quem ad nostrum gerit et gessit conventum.

W konwencie wrocławskim miała się wreszcie odbyć kapituła generalna. Możemy się spodziewać, że generał Tomasz z Fermo - wykazujący dużą troskę o północne prowincje i szkolnictwo zakonne, nazywany przez współczesnych vir magne prudentie - był osobiście zainteresowany rozwiązaniem problemów studium generale w polskiej prowincji. Wybór Wrocławia na miejsce kapituły był częścią przemyślanego programu Tomasza. Dwie poprzednie kapituły odbyły się w Erfurcie (1403) w prowincji saskiej i w Norymberdze (1405) w prowincji niemieckiej. Kolejnym etapem długotrwałej podróży generała po północnych prowincjach zakonu ${ }^{91}$ miała być wizytacja prowincji polskiej. Jesienią 1406 r. generał zawrócił jednak niespodziewanie na południe i pod koniec listopada był już w Fiesole, niedaleko Florencji, skąd prawdopodobnie powiadomił polskich dominikanów o zmianach dotyczących miejsca kapituły ${ }^{92}$. Być może z powodu zimy droga z Italii na Śląsk zajęła generalskiemu listowi aż dwa miesiące. Pewne jest zaś, że docierając do rąk prowincjała, pismo niweczyło ostatecznie plany wiązane z odbyciem posiedzenia kapituły.

Wiele wskazuje na to, że całe przedsięwzięcie z przejęciem przez wrocławską szkołę obowiązków Krakowa szybko skończyło się niepowodzeniem. Brakuje najważniejszego elementu, czyli decyzji kapituły generalnej. Przed lutym 1407 r. mogła ją podjąć wyłącznie norymberska kapituła z 1405 r., ta sama, która wskazała Wrocław na miejsce kolejnych obrad. W jej aktach czytamy jednak wyłącznie o mianowaniu nowego regensa dla studium generale w Bolonii ${ }^{93}$. Używanie tytułu regensa przez

\footnotetext{
${ }^{87}$ APWr., rep. 58, nr 153 i 154.

${ }^{88}$ APWr., rep. $57 \mathrm{nr} 59$ (111), 60 (112).

${ }^{89}$ APWr., rep. 57, nr 49 (102); J. K ł o c z o w s k i, Dominikanie polscy, s. 166-167.

${ }^{0}$ APWr., rep. 57, nr 56 (108). W dokumencie stanowiącym kartę ochronną kodeksu BUWr, rkps I F 653, znajduje się informacja na temat sporu o czynsz pomiędzy Piotrem Wasserrabe a Elżbietą z Legnicy.

${ }^{91}$ ACGOP III, s. 110-133; F. B a r t o 1 a c c i, R. L a m b e r t in i, Tommaso da Fermo, da baccelliere a Bologna a generale dell'ordine, Memorie Dominicane. Nuova Serie 45, 2014,

92 Tamże, s. 86-87; R. P. M o r t i e r, Histoire des maîtres généraux de l'Ordre des frères prêcheurs, t. IV, Paris 1909, s. 14-15. Prawdopodobne wydaje się, że jakieś fragmenty listu generała zachowały się w dokumencie prowincjała Ludolfa z 1517 r., w którym znalazł się fragment pisma Tomasza $\mathrm{z}$ Fermo dla konwentu brzeskiego, datowanego w listopadzie nieznanego roku z imieniem Arnsberga (T. G a ł u s z k a, Podział dominikańskich, s. 129-130).

${ }^{93}$ ACGOP III, s. 129.
} s. 86 . 
Gerstmana już przed kolejną kapitułą, czyli jeszcze bez jej zgody, musiało być naganną samowolą lub wyrazem niezwykłej pewności co do zatwierdzenia takiego stanu rzeczy. Z całą pewnością była to oddolna inicjatywa wrocławskich braci, początkowo popierana przez prowincjała, który w późniejszym czasie zmienił jednak zdanie w trosce o utrzymanie jedności prowincji. Nie wiemy niestety, czy omawiana sprawa stawała na kapitule generalnej, która ostatecznie zebrała się $13 \mathrm{~V} 1407 \mathrm{r}$. w Bolonii. Jej akta zachowały się w szczątkowej formie ${ }^{94}$. Nie dysponujemy również aktami kapituł prowincjalnych z tego czasu ani żadnymi wzmiankami dotyczącymi asygnowania braci na studia do Wrocławia.

Decydujący w sprawie przenosin studium musiał być opór krakowskich braci i ich przeora, a może także dworu na Wawelu ${ }^{95}$. Jest interesujące, że żaden z braci, którzy zapisali się w 1407 r. na Uniwersytet Krakowski, nie był związany ze Śląskiem: jeden przybywał z konwentu toruńskiego, a drugi reprezentował miejscowy klasztor Trójcy Świętej. Uważam, że ostateczna decyzja w sprawie studium generalnego została podjęta na kapitule prowincjalnej z jesieni 1407 r., w momencie załamania się wpływów stronników wrocławskiego projektu i wzrostu znaczenia zwolenników „programu krakowskiego”. Krakowską inicjatywą był także wyjazd Andrzeja Wężyka z Giebułtowa na Uniwersytet Praski. Ten krakowski mistrz sztuk, a od niedawna także dominikanin, udał się wiosną 1408 r. do Pragi, gdzie miał swoje wykształcenie poszerzyć o teologię ${ }^{96}$. Nie uzyskał tam jednak magisterium. Jego wyjazd wiązał się, moim zdaniem, z pewnego rodzaju misją. W Pradze przebywał wszak wtedy Falkenberg. Władze polskiej prowincji mogły próbować nakłonić go do powrotu, a na pewno musiały wyjaśnić jego sytuację.

Tymczasem na początku 1409 r. Falkenberg wyjechał z Pragi, żeby wziąć udział w soborze pizańskim. Na liście uczestników soboru znalazł się w otoczeniu generała zakonu, jak gdyby nigdy nic, jako przedstawiciel de provincia Polonie, regens Cracovie $^{97}$. Oznacza to, że studium nadal było w Krakowie, a Falkenberg był (przynajmniej formalnie) uważany za jego przełożonego. Niemal w tym samym czasie Jan Biskupiec tytułował się już profesorem teologii i jako wikariusz prowincjała dla

94 Tamże, s. 134; Fragmentum actorum capituli generalis Bononiae a. 1407 celebrati, wyd. G. Meersseman, Archivum Fratrum Praedicatorum 22, 1952, s. 196-200; zob. P. M o r t i e r, Histoire des maîtres généraux, t. IV, s. 79-81.

${ }^{55}$ Na temat związków Jana Biskupca z dworem zob. J. T u r e k, Jan Biskupiec, prowincjał polskich dominikanów w latach 1411-1417, w: Ecclecia, Regnum, fontes. Studia z dziejów średniowiecza, Warszawa 2014, s. 87-95.

${ }^{96}$ W. B u c i c h ow s ki, Lista, s. 84, nr 63; K. K a c z m a r e k, Szkoły, s. 403-404, nr 6. W styczniu 1408 r. Wężyk występował jako członek konwentu Trójcy Świętej (Starodawne prawa polskiego pomniki, t. II, wyd. A. Z. Helcel, Kraków 1870, nr 1133). Jego wyjazd był zapewne uzgadniany z prowincjałem, choć wiadomo, że w kwietniu Arnsberg był w Gdańsku (Zf, dodatek nr 3). W lipcu Wężyk był już w Pradze, zob. notę właścicielską w kodeksie: Zakład Narodowy im. Ossolińskich, rkps 376/II. Jeszcze w 1409 r. Andrzej był członkiem komisji egzaminacyjnej na Wydziale Sztuk w Pradze (Liber decanorum, s. 404).

${ }^{97}$ H. M i 11 e t, Les pères du Concile de Pise (1409): édition d'une nouvelle liste, Mélanges de l'Ecole française de Rome. Moyen-Age, Temps modernes 93, 1981, nr 2, s. 746; J. T u r e k, Regens krakowski Jan z soboru pizańskiego w świetle dwóch traktatów Jana Falkenberga, Przegląd Tomistyczny 16, 2010, s. 43-57. 
kontraty małopolskiej stał się bliskim współpracownikiem Arnsberga ${ }^{98}$. To kolejny dowód na zamianę układu sił w prowincji, w efekcie której zwycięstwo odniosła frakcja prokrakowska. Rok później w Bolonii, gdzie znowu zebrała się kapituła generalna, Biskupiec został mianowany mistrzem teologii i regensem krakowskim ${ }^{99}$. Pamiętajmy, że miesiąc przed tą kapitułą (4 IV 1410) Gerstman znowu był (tym razem obok Ambrożego) tytułowany lector domus. Uważam jednak, że projekt przeniesienia studium upadł już wcześniej w wyniku niepowodzenia wrocławskiej kapituły, a zapewne nigdy nawet nie został zrealizowany. Takie zabiegi musimy zatem uznać za kolejny przejaw rywalizacji dwóch największych klasztorów prowincji, krakowskiego i wrocławskiego. Niegasnących napięć na tym tle w kolejnych latach dowodzi zachowany $\mathrm{w}$ formularzu list prowincjała wysłany $\mathrm{z}$ Wrocławia $\mathrm{w}$ przededniu bolońskiej kapituły ${ }^{100}$. Arnsberg pisał w nim do nieznanego adresata - anonimowego mistrza teologii stojącego blisko generała i kurii papieskiej (może samego Falkenberga?) - że z powodu choroby nie może go osobiście powiadomić o postanowieniach kapituły generalnej odnośnie do polskiej prowincji. Wspominał jednak o poparciu udzielonym byłemu prowincjałowi (a więc Wasserrabemu) ${ }^{101}$ i staraniach o zgodę wśród braci. Zapewniał, że w prowincji panuje teraz inter fratres pax. Sędziwy już Wasserrabe w dalszym ciągu budził więc emocje. Miał zatem rację Długosz, pisząc o nim: Post cuius mortem divisio in prouincia inter Polonos et Alemanos facta $e s t^{102}$ i łącząc $\mathrm{z}$ jego osobą rychły podział prowincji. Wprowadzający ów podział w połowie 1415 r. następca Tomasza z Fermo,, generał Leonard Dati z Florencji, dał przełożonemu nowej prowincji zgodę na wysyłanie studentów do Paryża lub ad

98 Zbiór dokumentów małopolskich, wyd. I. Sułkowska-Kurasiowa, S. Kuraś, t. V, Wrocław 1970, nr 1225.

99 ACGOP III, s. 141; Biblioteka Kórnicka PAN, rkps 93, De rebus Provinciae Poloniae S. Hyacinthi Ord. Praedicatorum, k. 243.

${ }_{100} \mathrm{Zf}, \mathrm{nr} 112$. List nosi jedynie datę dzienną (10 maja), ale na podstawie kilku jego elementów (w tekście wymieniono Aleksandra V i kapitułę generalną) wydawca datował go na ok. 1410 r. i przypisywał Arnsbergowi lub Biskupcowi (J. Fi j a ł e k, Wstęp, w: Zf, s. 224225). Sam opowiedziałem się $\mathrm{w}$ innym miejscu za tą drugą postacią (J. T u r e k, Podział, s. 292-294). Informacja o pobycie Arnsberga we Wrocławiu w kwietniu 1410 r. (APWr., rep. $58, \mathrm{nr} 172$ ) każe zrewidować to twierdzenie. Jest to ostatnia pewna wzmianka na temat tego prowincjała. Jego imię nie pojawia się w aktach kapituły generalnej, nawet wśród prowincjałów zwolnionych ze swoich obowiązków (ACGOP III, s. 141, 147). Przyjmuje się, że Arnsberg zmarł w drugiej połowie 1410 r. (R.-J. L o e n e rt z, Une ancienne chronique, s. 38-39; T. G ału s zk a, Podział, s. 118-119).

${ }^{101}$ W liście występuje Jan, ale Arnsberg nie miał żyjącego poprzednika o tym imieniu. Nie można jednak zapominać, że tekst zachowała się w księdze formularzowej, co dopuszcza wprowadzanie zmian uniemożliwiających rozpoznanie wymienionych osób. Wiosną $1410 \mathrm{r}$. we Wrocławiu Arnsberg mógł spotkać (i spotkał) tylko jednego swojego poprzednika, Piotra Wasserrabe.

102 R.-J. L o e n e rtz, Une ancienne chronique, s. 38. Ostatni raz wspomniany w dokumencie konwentu wrocławskiego z 1410 r. (APWr., rep. 58, nr 172). Jego imię z informacją o anniwersarzu zapisano w Nomina fratrum mortuorum in conventu $S$. Adalberti (BUWr, rkps IV F 222, k. 39). W literaturze często błędnie podaje się, że Piotr zmarł ok. 1407 r. (P. K i e 1 a r, Studia nad kulturą, s. 391; W. B u c i c h ow s ki, Lista, s. 192, nr 889; K. K a c z m a re k, Szkoły, s. 422, nr 82). 
alia studia generalia extra suam provinciam ${ }^{103}$. Oznacza to pogrzebanie nadziei na własne studium. Nadzieje te odżyły jednak sto lat później ${ }^{104}$.

IV.

Spróbujmy podsumować powyższe rozważania. We wrocławskim konwencie na przełomie XIV i XV stulecia przebywało równocześnie kilku wykładowców. W kulminacyjnym roku 1404 spotykamy nawet pięciu lektorów i kursora. Jeden z nich pracował jako lektor katedralny, pozostali wykładali w poszczególnych szkołach na terenie konwentu. W tym czasie działały tu bowiem nieprzerwanie konwentualna szkoła teologii i wszystkie trzy rodzaje studiów partykularnych - artium, filozofii i teologii. Źródła z tego okresu poświadczają występowanie wśród wrocławskich dominikanów tytułów wywodzących się z prowincji niemieckiej i saskiej-lector domus i lector regens. Pierwszy oznaczał lektora głównego (lector principalis), który kierował pracami konwentualnej szkoły teologii lub partykularnej studium teologii. Drugi tytuł należy odnieść do próby uruchomienia we Wrocławiu studium generalnego. Podjęto ją w 1407 r. w związku z zapowiadaną wizytacją generała Tomasza z Fermo i obradami kapituły generalnej. Pomysłodawcą takiego projektu był zapewne były prowincjał, Piotr Wasserrabe, który zdołał pozyskać też swojego następcę, Jana Arnsberga. Regensem miał zostać jeden z lektorów - Piotr Gerstman. Wrocławski konwent dysponował odpowiednią kadrą naukową, świetnie wyposażoną biblioteką i zapleczem ekonomicznym. Studium generale nie miało być tworzone od początku, ale przeniesione z Krakowa, gdyż po nagłym wyjeździe regensa Jana Falkenberga i w obliczu braków kadrowych napotkało na poważne problemy w dalszym tam funkcjonowaniu. Inicjatywa niewątpliwie wyszła od wrocławskich braci, ale trudno sobie wyobrazić, aby działali oni samodzielnie. Uruchomienie studium generalnego dotyczyło całej prowincji i było zbyt poważnym przedsięwzięciem, aby rozpoczynać je bez zgody prowincjała. Bez niej od początku byłoby skazane na niepowodzenie. $\mathrm{Na}$ aprobatę Arnsberga wskazuje zaś jednoznacznie fakt, że słów lector regens użyto w dokumencie wystawionym w jego obecności i uwierzytelnionym jego pieczęcią. Całe przedsięwzięcie związane z przeniesieniem studium prędko (może jeszcze w 1407 r.) zakończyło się niepowodzeniem w wyniku przeniesienia obrad kapituły generalnej do Bolonii i niewątpliwego oporu braci z krakowskiego konwentu. Konflikt, który narósł na tym tle pomiędzy braćmi $\mathrm{z}$ dwóch najważniejszych ośrodków prowincji, Wrocławia i Krakowa, postawił prowincjała przed trudnym zadaniem doprowadzenia do pacyfikacji i utrzymania jedności prowincji. Sprawa studium stanęła ponownie na jesiennej kapitule prowincjalnej w 1407 r., na której podjęto decyzję o skierowaniu na Uniwersytet Krakowski przeora krakowskiego. Bracia z konwentu w Krakowie zdołali przeforsować swoje stanowisko i wyszli z tego sporu zwycięsko. Powstałe na tej płaszczyźnie napięcia stały się niebawem jedną z przyczyn podziału polskiej prowincji dominikanów.

103 J. T u re k, Podział, dodatek nr 1.

104 K. K a c z m a r e k, Konwent, s. 152-157. 


\section{BIBLIOGRAFIA}

Bartolacci F., Lambertini R., Tommaso da Fermo, da baccelliere a Bologna a generale dell'ordine, Memorie Dominicane. Nuova Serie 45, 2014.

Boockmann H., Johannes Falkenberg, der deutsche Orden und die polnische Politik, Göttingen 1975.

Bucichowski W., Lista lektorów dominikańskich prowincji polskiej (od erygowania prowincji do roku 1525), Przegląd Tomistyczny 6-7, 1997.

Bünger F., Ein Dominikaner Provinzialkapitel in Luckau (1400), Zeitschrift für Kirchengeschichte 34, 1913.

Ciesielska K., Wykazy mieszczan toruńskich zobowiązanych do udziału w wyprawach krzyżackich na Gotlandię w latach 1398-1408, Zapiski Historyczne 32, 1967, z. 4.

Dola K., Wrocławska kapituła katedralna w XV wieku. Ustrój - skład osobowy - działalność, Lublin 1983.

Gałuszka T., Fragmenty czternastowiecznych akt kapituł prowincjalnych dominikanów polskich w zbiorach Bayerische Staatsbibliothek w Monachium. Kapituła prowincjalna w Opatowcu w 1384 r., Studia Źródłoznawcze 51, 2013.

Gałuszka T., Podział dominikańskich okręgów klasztornych na Kujawach w połowie XIV wieku. Studium dokumentu prowincjała Ludolfa z 1517 roku, Roczniki Historyczne 80, 2014.

Gałuszka T., Studium generalne dominikanów polskich w XIV wieku?, Folia Historica Cracoviensia 20, 2014.

Gałuszka T., Szkolnictwo konwentualne i partykularne w strukturach polskiej prowincji dominikanów XIV stulecia. Nowe ujęcie w świetle nowych źródeł, Roczniki Historyczne 78, 2012.

Gargan L., Lo studio teologico e la biblioteca dei domenicani a Padova nel tre e quattrocento, Padova 1971.

Kaczmarek K., Głos w dyskusji nad powstaniem Studium Generalnego dominikanów w Krakowie, Nasza Przeszłość 91, 1999.

Kaczmarek K., Konwent dominikanów wrocławskich w późnym średniowieczu, Wrocław 2008.

Kaczmarek K., Szkoły i studia polskich dominikanów w okresie średniowiecza, Poznań 2005.

Kadlec J., Řeholní generálni studia při karlově universitě v době předhusitské, Acta Universitatis Carolinae, Historia Universitatis Carolinae Pragensis 7, 1966, fasc. 2.

Kaeppeli T., La raccolta di discorsi e di atti scolastici di Simone da Cascina O. P. († ca. 1420), Archivum Fratrum Praedicatorum 12, 1942.

Kałuża Z., Chronologie des premieres discussions ecclesiologiques a Cracovie (1404-1407), Rivista di storia della filosofia 52, 1997, nr 1.

Kielar P., Organizacja szkolnictwa dominikańskiego w XIV wieku, Studia Philosophiae Christianae 5, 1969, z. 1.

Kielar P., Studia nad kulturą szkolną i intelektualną dominikanów prowincji polskiej w średniowieczu, w: Studia nad historią dominikanów w Polsce 1222-1972, t. I, Warszawa 1975.

Kłoczowski J., Dominikanie polscy na Śląsku w XIII-XIV wieku, Lublin 1956.

Kras P., Dominican inquisitors in medieval Poland (14th -15 th c.), w: Praedicatores inquisitores, t. I: The Dominicans and the Mediaeval Inquisition, Roma 2004.

Kubicki R., Dominikanie w Nordenborku i Gierdawach w XV - początkach XVI w., Komunikaty Mazursko-Warmińskie 2012, nr 2 (276).

Kubicki R., Środowisko dominikanów kontraty pruskiej od XIII do połowy XVI wieku, Gdańsk 2007.

Latkowski A., Magister Franciszek Oczko OP, Przegląd Tomistyczny 2, 1986.

Latkowski A., Magister Piotr Wichman OP, Przegląd Tomistyczny 2, 1986.

Loenertz R.-J., Une ancienne chronique des provinciaux dominicains de Pologne, Archivum Fratrum Praedicatorum 21, 1951.

Löhr G. M., Breslauer Dominikaner des 15. Jahrhunderts auf auswärtigen Hochschulen, Archivum Fratrum Praedicatorum 13, 1943. 
Löhr G. M., Die Dominikaner an der Leipziger Universität, Vechta 1934.

Löhr G. M., Die Kölner Dominikanerschule vom 14 bis zum 16 Jahrhundert. Mit einer Übersicht über die Gesamtenwicklung, Freiburg 1946.

Meijer G. A., Het Jakopijnenklooster te Groningen, Archief voor de geschiedenis van het Aartsbisdom Utrecht 32, 1907.

Millet H., Les pères du Concile de Pise (1409): édition d'une nouvelle liste, Mélanges de l'Ecole française de Rome. Moyen-Age, Temps modernes 93, 1981, nr 2.

Mortier R. P., Histoire des maîtres généraux de l'Ordre des frères prêcheurs, t. IV, Paris 1909.

Mulchahey M. M., „First the Bow is Bent in Study...”. Dominican Education before 1350, Toronto 1998.

Myszka Ł., Dominikanie w Toruniu od XVI do XIX wieku. Katolicki zakon w protestanckim mieście, Kraków 2015.

Ożóg K., Kościół krakowski wobec wielkiej schizmy zachodniej i ruchu soborowego u schyłku XIV i w pierwszej połowie XV wieku, w: Kościół krakowski w życiu państwa i narodu polskiego, Kraków 2002.

Roest B., A History of Franciscan Education (c. 1201-1517), Leiden 2000.

Seńko W., Trzy traktaty Jana Falkenberga na temat tyranobójstwa przedstawione na soborze w Konstancji w 1416 r., Przegląd Tomistyczny 10, 2004.

Senner W., Meister Eckhart's life, training, career, and trial, w: A Companion to Meister Eckhart, Leiden 2013.

Stopka K., Szkoły katedralne metropolii gnieźnieńskiej w średniowieczu. Studia nad kształceniem kleru polskiego w wiekach średnich, Kraków 1994.

Świerk A., Fragmenty piętnastowiecznego katalogu biblioteki wrocławskich dominikanów, Śląski Kwartalnik Historyczny. Sobótka 21, 1966.

Turek J., Podział polskiej prowincji dominikanów w czasach prowincjalatu Jana Biskupca w latach 1415-1417, Przegląd Historyczny 106, 2015, z. 2.

Turek J., Regens krakowski Jan z soboru pizańskiego w świetle dwóch traktatów Jana Falkenberga, Przegląd Tomistyczny 16, 2010.

Wattenbach W., Über das Handbuch eines Inquisitors in der Kirchenbibliothek St. Nicolai in Greifswald, Abhandlungen der Königl. Akademie der Wissenschaften zu Berlin 1888, IV.

Zajchowska A., Franciszek Oczko i początki reformy obserwanckiej w polskiej prowincji dominikanów, Średniowiecze Polskie i Powszechne 4, 2012.

Zawadzka K., Biblioteka klasztoru dominikanów we Wrocławiu (1226-1810), w: Studia nad historią dominikanów w Polsce 1222-1972, t. II, Warszawa 1975.

Zdanek M., Inkwizytorzy dominikańscy w diecezji krakowskiej w średniowieczu, w: Inkwizycja papieska w Europie Środkowo-Wschodniej, Kraków 2010.

Zdanek M., Regensi dominikańskiego studium generalnego w Krakowie do 1596, Przegląd Tomistyczny 16, 2010.

Zdanek M., Szkoły i studia dominikanów krakowskich w średniowieczu, Kraków 2005. 


\title{
An attempt to organise a studium generale of the Dominicans in Wroclaw at the beginning of the $15^{\text {th }}$ century
}

\author{
Summary
}

One of the lecturers listed in the document of the Dominicans of Wrocław dated 3 February 1407 appears with the title of lector regens. That title was used by those brethren who lectured at the conventual school of theology or one of particular schools. The title of regens was reserved for the director of the studium generale, the highest school in the hierarchy of monastic education. It is assumed that at the beginning of the $15^{\text {th }}$ century at the latest such studium was formed in Cracow. Therefore a question appears whether two such schools may have been founded in two monasteries of the Polish province of Dominicans. The answer should be sought first through analysis of the faculty membership in the Wrocław monastery. At the turn of the $14^{\text {th }}$ and $15^{\text {th }}$ centuries a number of lecturers stayed in Wrocław. In 1404 there were as many as five lecturers and one cursor. One of them worked as the cathedral lecturer, the others lectured in particular schools of the convent, as there were at the same time the conventual school of theology and all three types of particular schools - of logic, philosophy and theology. Sources of the period confirm the use of the titles lector domus and lector regens, which were of German and Saxon provenience, among the Wrocław Dominicans. The first of them indicated the main lecturer (lector principalis), who directed the work of the conventual school of theology and particular school of theology. The second title should be interpreted as an attempt at forming the studium generale in Wrocław. It took place in 1407, under favourable conditions provided by well-educated lecturers, well-equipped library and adequate economic support. The impulse was the expected visitation of the general Thomas de Firmo and general chapter meeting. The initiative belonged to the Dominicans of Wrocław, who cherished the separatist tendencies and rivalry with Cracow. The originator of the project was Peter Wasserabe, who managed to convince the provincial John Arnsberg. The studium generale was not intended to be created from the beginning, but moved from Cracow, where after the sudden departure of the regens John Falkenberg and facing problems with the number of faculty members, serious doubts to the possibility of its functioning appeared. However, the whole undertaking ended without success because the meeting of the general chapter was moved to Bologna and also because the brethren of Cracow fervently opposed the idea. 